\title{
Perceptions of Service Quality and Corporate Image Against Satisfaction and Customer Loyalty
}

\author{
Siti Maria1, Yundi Permadi Hakim², and Dio Caisar Darma² \\ ${ }^{1}$ Management Program, Faculty of Economic and Business, Mulawarman University, Samarinda, \\ Indonesia (75119) \\ ${ }^{2}$ Management Program, High College of Economics Science, Samarinda, Indonesia (75242)
}

Corresponding Author:

Dio Caisar Darma

dio.cessar@yahoo.com

Received: 30 December 2019 Accepted: 29 January 2020 Published: 6 February 2020

Publishing services provided by Knowledge E

(c) Siti Maria et al. This article is distributed under the terms of the Creative Commons

Attribution License, which permits unrestricted use and redistribution provided that the original author and source are credited.

Selection and Peer-review unde the responsibility of the 6 th ICOEN 2019 Conference Committee.

\begin{abstract}
The purpose of the study looked at the influence: (1) Perceptions of service quality and corporate image directly on customer satisfaction; (2) Perceptions of service quality, corporate image, and satisfaction directly on customer loyalty; (3) Perceptions service quality and corporate image indirectly on loyalty through customer satisfaction at Travel Prima. The type of research data used comes from the primary (interview questionnaire to the respondent) and secondary (scientific books, articles, or internet). The data is processed quantitatively by path statistical analysis method using SPSS version 23.0. The conclusion of the analysis results can be drawn is: (1) Perceptions of service quality and corporate image directly have a significant positive effect against customer satisfaction; (2) Perceptions of service quality, corporate image, and satisfaction directly have a significant positive effect against customer loyalty; (3) Perceptions of service quality and corporate image indirectly have a significant positive effect against loyalty through customer satisfaction at Travel Prima (Samarinda City).
\end{abstract}

Keywords: perceptions of service quality; corporate image; satisfaction; customer loyalty

\section{Introduction}

The importance of knowing customer satisfaction is an evaluation of the company's performance, especially the quality of service that has been given. By knowing the customer perceptions of the quality of service, is the input material for the company which things of service quality is considered still less, to be repaired immediately. The importance of appraisal of service quality dimensions is used as a strategic planning framework and analysis in the marketing of services or services [3]. Service quality dimensions include: reliability, alertness, assurance, empathy, and concrete manifestations.

The company's marketing strategy must be active and dynamic, because the marketing strategy must always adjust to consumer purchasing policies. Consumer behavior 
always changes importance because consumer spending increases motivation for educational change, encourages social and cultural change and other factors that cause behavior change. These changes in consumer buying behavior must be continuously monitored or followed by producer companies, because consumer buying behavior towards a product is needed by many factors. The company intended to discuss the company in order to achieve the target to meet customer needs, in order to maintain competition. The company also demands interests, perceptionss, preferences and buying behavior. Consumers as individuals who have criteria and conditions that are different from each other and this difference also raises the complexity of consumers [14].

Samarinda City is the capital of East Kalimantan Province, with the population of Samarinda City reaching 828,303 people, with a density of $1,155.99$ people per $\mathrm{km}^{2}$ [2]. From the total population, most of them are immigrants, so the mobility of people coming out and entering Samarinda is so great and it is natural that many companies are engaged in traveling services that open branches or open companies in the travel services sector in Samarinda, especially Travel Prima.

Travel Prima engaged in travel services realize that it is necessary to know to what extent costumer perceptionss of the quality of services that have been given so far whether it has provided satisfaction for cotumers, but it is necessary to know how the company image in the eyes of cotumers.

Customer satisfaction can create loyalty or customer loyalty to companies that provide excellent service and quality because of the high level of customer satisfaction is very important. Customers who have achieved satisfaction are very likely to tell their friends, colleagues and others the experience they get about the company's products or services. With the creation of an optimal level of customer satisfaction then encourage the creation of loyalty in the minds of customers who already feel satisfied. Customer loyalty is seen as the strength of the relationship between a person's relative and recurring business attitudes.

Based on the results of interviews in the field, there are still some complaints from respondents about the discrepancy between expectations and reality in the service and corporate image of Travel Prima. This is evident from the responses of respondents who feel less satisfied than perceptions of service quality factors such as: reliability of the density of departure schedules, responsibility for complaints, and the wishes of consumers who have not been accommodated to the image of travel travel services that are considered still expensive. 
This research is a development of empirical findings [5]. The results showed that the quality of the service directly positive and significant effect on corporate image and customer satisfaction. Service quality has a positive and insignificant effect on customer loyalty. Price perceptions has a positive and significant effect on corporate image, customer satisfaction, and customer loyalty. Corporate image has a positive and significant effect on customer satisfaction. Corporate image has a positive and insignificant effect on customer loyalty.

Based on the background, while the goal to be achieved in this study is to analyze: (1) Influence of perceptions of service quality and corporate image directly against customer satisfaction; (2) Influence of perceptions of service quality, corporate image and satisfaction directly against customer loyalty; (3) Influence of perceptions of service quality and corporate image indirectly against loyalty through customer satisfaction at Travel Prima (Samarinda City).

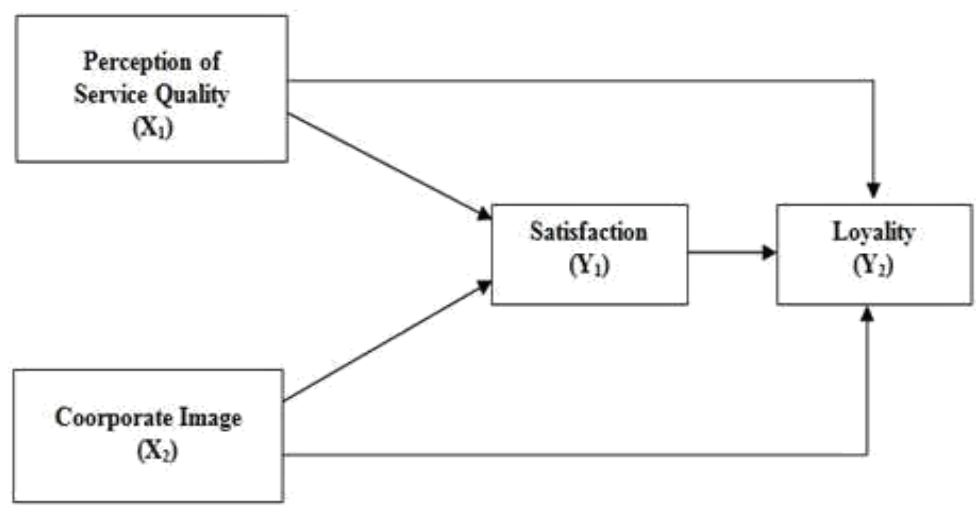

Figure 1: Research Framework.

Based on the description of the theories that have been put forward as well as the existing problems, it is necessary to create a research conceptual framework (Figure 1).

\section{Methods}

\subsection{Operational Definition}

An operational definition is needed to provide clearer operating criteria of the meaning and limitations of each of the variables used in this study. The definition is as follows:

- Dependent or exogenous variable is a number of symptoms with various elements /factors that exist within which determine/influence the existence of other variables. In this case the free variable is:

- Perceptions of service quality $\left(\mathbf{X}_{1}\right)$ 
Perceptions of quality is the view of customer on the quality of services provided by Travel Prima Samarinda City with indicators: reliability, responsiveness and empathy.

- Corporate image $\left(\mathbf{X}_{2}\right)$

Corporate image is the credibility or is the level where customer feel that the Travel Prima Samarinda City has the knowledge or ability to meet its demands and whether can be trusted to tell the truth or not with the indicator: a reliable company, able to serve the customer and performance good company.

- Intervening variables, namely the variables that mediate the relationship between independent variables with the dependent variable, namely customer satisfaction $\left(\mathbf{Y}_{1}\right)$. Customer satisfaction is the evaluation of customer's purchase Travel Prima Samarinda City where the selected alternatives at least equal or exceed customer expectations with indicators: customer attitudes, existing facilities and rates that compete.

- Dependent variable or endogenous, that is variable influenced by other variable. In this study the dependent variable is customer loyalty $\left(\mathbf{Y}_{2}\right)$. Loyalty is a loyal customer on Travel Prima Samarinda City that tends to be tied and will buy the same product again even though there are many other alternatives available with indicators: provide recommendations, increase the number of transactions and will not move to another travel.

\subsection{Types and Sources of Data}

The type of data used is subject data. Thus, the data used is from the results of respondents' answers to questions raised in interviews, either orally or in writing. The research data consists of 2 sources, namely primary and secondary are described below:

- Primary data

Primary data is data collected through research obtained directly from the source [7]. In this case, obtained from the respondent who answered the question. On the basis of this method is expected to hit the target, because the subject (customer) is considered most know against the Travel Prima Samarinda City.

- Secondary Data 
In this study, the secondary data obtained is data supporting the number of customers Travel Prima Samarinda City or component data that if necessary to arrange this research.

\subsection{Population and Sample}

In this study the population in question is the Travel Prima Samarinda City users who have been using service several times in the area of Samarinda City operations. Thus, the population in this study that is all consumers who have 3 times using the services of Travel Prima Samarinda City (majors Samarinda-Balikpapan).

The sample in this study is Travel Prima customer of Samarinda City which has more than 3 times using travel services with limitation (destination of Samarinda City to Balikpapan). The number of samples used in this study amount is determined as many as 60 samples with the consideration that the number of population is not known for certain. The number of samples as many as 100 are considered to be representative, because the minimum number of samples for the correlation data of at least 30 samples [13].

\subsection{Research Instruments}

The collected data were first tested using the normality, reliability and validity test. Here is the explanation:

- Normality test

Normality test aims to test whether in the regression model, the dependent variable and the independent variable both have a normal distribution. A good regression model is to have normal or near-normal data distribution.

- Reliability test

Reliability testing is intended to measure a questionnaire which is an indicator of construct variables. A questionnaire is said to be reliable or reliable if one's response to a statement is consistent or stable over time.

- Validity test

Validity test is used to measure the validity or validity of a questionnaire. A questionnaire is said to be valid if the question on the questionnaire is able to reveal something that the questionnaire will measure. 


\subsection{Analysis Tool}

Descriptive analysis is the analysis shown on the development and growth of a situation and only provides a picture of a particular situation by describing the nature of the object of the study [15].

The data analysis model used is path analysis with some prior testing, such as data quality test (validity and realibiltas test). The purpose of data analysis methods is to interpret and draw conclusions from a number of collected data. Researchers use SPSS software version 23.0 to process and analyze data research results.

The analysis used is path analysis or called path analysis because between perceptions variable of service quality and corporate image to customer loyalty as customer satisfaction intervening. Path analysis is a technique for analyzing the causal relationships that occur in multiple regression if the independent variables affect the dependent variable not only directly but also indirectly [10].

Testing the significance of each of the calculated path coefficients, either individually or collectively, and testing the differences in the effect of each exogenous variable on endogenous variables can be done with the following customer steps [11]:

- State the statistical hypothesis (operational hypothesis) to be tested.

- $\mathbf{H}_{0}: \mathrm{P}_{x u x i}=0$, meaning there is no effect of exogenous variable $\left(X_{u}\right)$ on the endogenous $\left(X_{i}\right)$ variable.

- $\mathbf{H}_{1}: \mathrm{p}_{x u x i} \neq 0$, it means that exogenous variable $\left(\mathrm{X}_{u}\right)$ exists on the endogenous $\left(X_{i}\right)$ variable. where, $\mathrm{u}$ and $\mathrm{i}=1,2, \ldots ., \mathrm{k}$

- Use the appropriate test statistic, is: to test each path coefficient, testing the coefficient of the path as a whole/together and testing the difference of influence of each exogenous variable to the endogenous variable.

- Take the conclusion, whether need trimming or not. In the event of trimming, the calculation must be repeated by eliminating the path which according to the test is not significant (no significant).

\section{Results}

\subsection{Testing Questionnaire Instrument}

Based on the calculations on the first and second sub-structural models, get the figure as below: 


\section{Normal P-P Plot of Regression Standardized Residual}

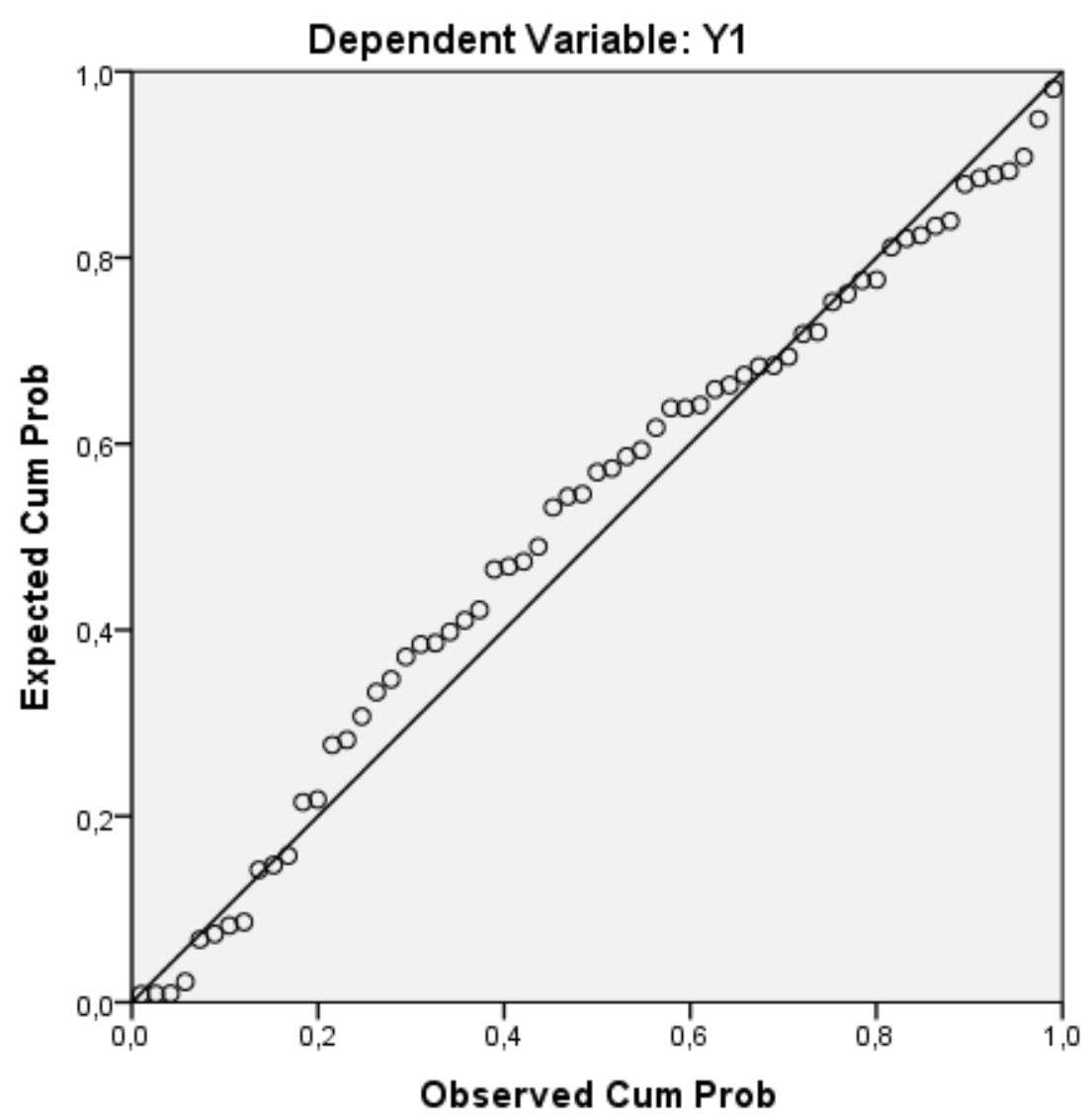

Figure 2: Normal P-P Plot (Customers Satisfaction) (Source: Output of SPSS).

First, the existing Figure 2 looks like a divergent straight line dividing the actual data will follow the diagonal line, so it can be said that the data of the existing customer satisfaction $\left(Y_{1}\right)$ formers are normally distributed.

From Figure 3 there is seen form divide straight line diagonal which depict actual data will follow diagonal line, so can be said data of customer loyalty shooter $\left(\mathrm{Y}_{2}\right)$ existing is normal distribution.

TABLE 1: Reliability Statistics $\left(\mathrm{Y}_{1}\right)$.

\begin{tabular}{|c|c|}
\hline Cronbach's Alpha & N of Items \\
\hline 709 & 3 \\
\hline
\end{tabular}

Source: Output of SPSS

Second, based on the results of the reliability test as shown in Table 1, the result of cronbach alpha $(0,709)>0,60$ means that all data in the first sub-structure model (customer satisfaction) has been reliable. 


\section{Dependent Variable: Y2}

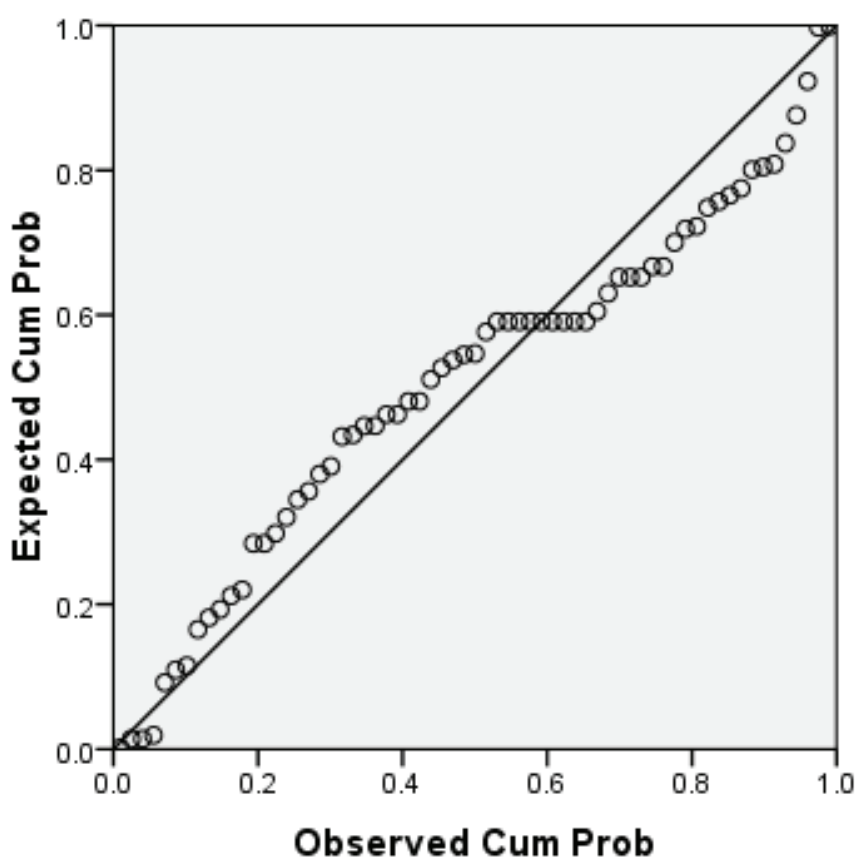

Figure 3: Normal P-P Plot (Customers Loyalty) (Source: Output of SPSS).

TABLE 2: Reliability Statistics $\left(\mathrm{Y}_{2}\right)$

\begin{tabular}{l|c} 
Cronbach's Alpha & N of Items \\
\hline 771 & 3 \\
\hline
\end{tabular}

Source: Output of SPSS

Meanwhile, from the results of the reliability test on the second sub-structural model, the result of cronbach alpha $(0,771)>0,60$ means that all data affecting the loyalty of the $\left(\mathrm{Y}_{2}\right)$ realibel (see Table 2).

The results of validity test for each question that contains in this research variable presented in table 3 which states that the validity test of the variables in the questionnaire $\left(X_{1}, X_{2}, Y_{1}\right.$ and $\left.Y_{2}\right)$ is valid, because the result of $r_{\text {value }}>r_{\text {table }}(0,250)$.

\subsection{Testing of Path Analysis}

This section describes each path in the model using path analysis. Each path tested shows the influence of perceptions of service quality and corporate image on satisfaction and customer loyalty. Before testing whether there is any direct or indirect effect, each path is tested for signification first. If there is a path that is not significant then 
TABLE 3: Validity Test Results.

\begin{tabular}{|c|c|}
\hline Variable & Starement \\
\hline \multirow[t]{3}{*}{$\begin{array}{l}\text { Perceptions of service } \\
\text { quality }\left(X_{1}\right)\end{array}$} & $\begin{array}{l}\text { Reliability in the form of timeliness } \\
\text { depart }\end{array}$ \\
\hline & Response to complaint \\
\hline & $\begin{array}{l}\text { A sense of empathy for the desire of } \\
\text { the customers }\end{array}$ \\
\hline \multirow[t]{3}{*}{ Corporate image $\left(X_{2}\right)$} & Trust in the company \\
\hline & Able to serve customers \\
\hline & Companies that perform well \\
\hline \multirow{3}{*}{$\begin{array}{l}\text { Customer satisfaction } \\
\left(Y_{1}\right)\end{array}$} & Friendly in serving \\
\hline & Excellent service (adequate facilities) \\
\hline & Competitive rates \\
\hline \multirow[t]{3}{*}{ Customer loyalty $\left(\mathrm{Y}_{2}\right)$} & Recommendations to others \\
\hline & Increase the number of trips \\
\hline & $\begin{array}{l}\text { No sense of desire to move other } \\
\text { travel }\end{array}$ \\
\hline
\end{tabular}

Source: Output of SPSS

\begin{tabular}{|c|c|}
\hline$r_{\text {value }}$ & $r_{\text {table }}$ \\
\hline 0,806 & 0,250 \\
\hline 0,871 & 0,250 \\
\hline 0,700 & 0,250 \\
\hline 0,819 & 0,250 \\
\hline 0,805 & 0,250 \\
\hline 0,861 & 0,250 \\
\hline 0,790 & 0,250 \\
\hline 0,817 & 0,250 \\
\hline 0,796 & 0,250 \\
\hline 0,847 & 0,250 \\
\hline 0,884 & 0,250 \\
\hline 0,874 & 0,250 \\
\hline & \\
\hline
\end{tabular}

applied trimming theory that is by removing or removing the path that is not significant Then from the results of the new structure is re-calculated each path coefficient.

Based on these results, it is known that the direct and indirect influence, and the influence of the total perceptions of service quality $\left(X_{1}\right)$ and corporate image $\left(X_{2}\right)$ as the exogenous variable to the endogenous variables namely loyalty $\left(Y_{2}\right)$ through customer satisfaction $\left(\mathrm{Y}_{1}\right)$ as intervening variable. The results of path analysis and hypothesis testing are described in Table 4.

TABLE 4: Value of Path Coefficient and Hypothesis Testing.

\begin{tabular}{l|c|c|c} 
Variable & Standardized Coefficient $(\beta)$ & $t_{\text {value }}$ & Sig \\
\hline$X_{1} \rightarrow Y_{1}$ & 0,342 & 2,345 & 0,023 \\
\hline$X_{2} \rightarrow Y_{1}$ & 0,377 & 2,581 & 0,012 \\
\hline$X_{1} \rightarrow Y_{2}$ & 0,314 & 2,412 & 0,019 \\
$X_{2} \rightarrow Y_{2}$ & 0,283 & 2,151 & 0,036 \\
$Y_{1} \rightarrow Y_{2}$ & 0,287 & 2,540 & 0,014 \\
$X_{1} \rightarrow Y_{1} \rightarrow Y_{2}$ & $0,342 \times 0,287=0,098$ & 1,722 & 0,008 \\
$X_{2} \rightarrow Y_{1} \rightarrow Y_{2}$ & $0,377 \times 0,287=0,108$ & 1,810 & 0,000
\end{tabular}

Source: Output of SPSS 
From the table above, the results of hypothesis testing showed that no path found to have an insignificant effect, so that no path is eliminated. In accordance with the framework of the concept of research, can be produced 2 linear functions, namely: function model sub-structure 1 and 2 . Both the resulting functions are simultaneously incorporated into a model path. Exogenous variables are variables that affect endogenous variables. The influence between exogenous and endogenous is described as follows:

- In sub-structure 1, exogenous variables $=X_{1}, X_{2}$ and endogenous variables $=Y_{1}$. The direct effect is calculated as in standardize regression weight (coefficient). In function-1, $X_{1}$ and $X_{2}$ have no indirect effect on $Y_{1}$. The total influence of each exogenous variable on $Y_{1}$ is equal to its direct effect. Writing function or model-1 in standardized form is:

$$
Y_{1}=0,342 X_{1}+0,377 X_{2}+0,501 \varepsilon_{1}
$$

Based on the path model that has been produced above, then can be interpreted as follows:

- The coefficient of perceptions of service quality $\left(X_{1}\right)$ is 0,342 meaning that if other exogenous variable have fixed value and $X_{1}$ increase $1 \%$ then customer satisfaction $\left(Y_{1}\right)$ will increase $34,2 \%$. Coefficient of positive value indicates a positive relationship between perceptionss of service quality to customer satisfaction, where the increasing value of perceptionss of service quality will increase the customer satisfaction.

- Coefficient of corporate image $\left(X_{2}\right)$ is 0,377 meaning that if other exogenous variable have fixed value and $X_{2}$ increase $1 \%$, then customer satisfaction $Y_{1}$ will increase $37,7 \%$. Coefficient of positive value signifies a positive relationship between the corporate image to customer satisfaction, where the increasing value of corporate image will also increase customer satisfaction.

In the path analysis function, we can illustrate the path model as follows:

- In sub-structure 2 , exogenous variables $=X_{1}, X_{2}$ and $Y_{1}$ and endogenous variables $=Y_{2}$.

In function-2 becomes the overall model in path analysis. The direct effect is calculated as in standardize regression weight (coefficient). The linear regression functions in standardized form are:

$$
Y_{2}=0,314 X_{1}+0,283 X_{2}+0,287 Y_{1}+0,393 \varepsilon_{2}
$$




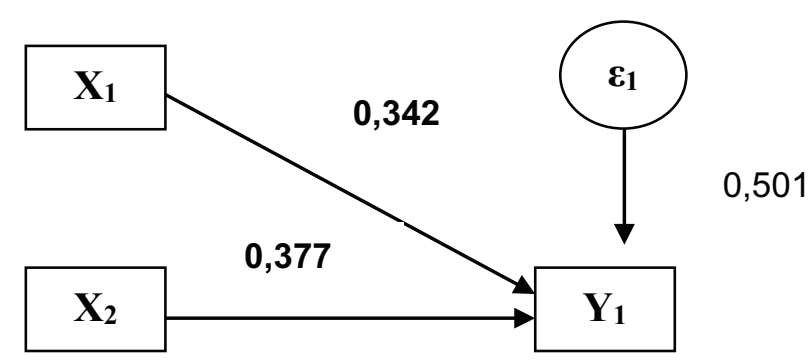

Figure 4: Relationship Structure $X_{1}$ and $X_{2}$ to $Y_{1}$.

Based on the path model generated above, the number can be interpreted as follows:

- The coefficient of perceptions of service quality $\left(X_{1}\right)$ is 0,314 meaning that if other exogenous

variable is fixed and $X_{1}$ increases 1 point, then customer loyalty $\left(Y_{2}\right)$ will increase 0,314 . Coefficient of positive value indicates a positive relationship between perceptionss of service quality to customer loyalty, where the increasing value of perceptions of service quality will increase customer loyalty.

- Coefficient of corporate image $\left(X_{2}\right)$ is 0,283 meaning other exogenous variable fixed value and $X_{2}$ has increase $28,3 \%$. Coefficient of positive value signifies a positive relationship between corporate image to customer loyalty, where the increasing value of corporate image will increase customer loyalty.

- The coefficient of customer satisfaction $\left(Y_{1}\right)$ is 0,287 means that if other exogenous variables are fixed and customer satisfaction $\left(Y_{1}\right)$ increases $1 \%$, then customer loyalty $\left(\mathrm{Y}_{2}\right)$ will increase by $28,7 \%$. Coefficient of positive value indicates a positive relationship between satisfaction with customer loyalty, where the increasing value of satisfaction will increase customer loyalty.

Based on the sub-structure function 2 used for the previous table, it can be described as follows:

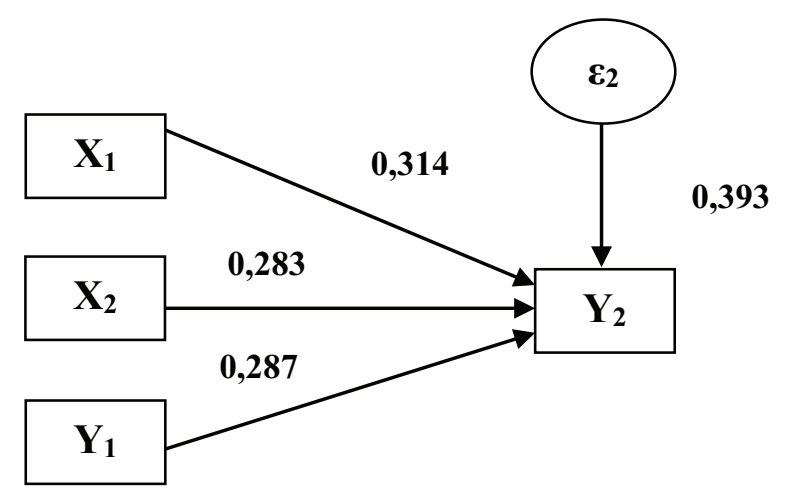

Figure 5: Relationship Structure $X_{1}, X_{2}$ and $Y_{1}$ to $Y_{2}$. 
The total effect is the sum of direct effects with indirect influence with this provision, then the total effect can be calculated by computing equations (1) and (2) substituted, is:

$$
\begin{gathered}
Y_{1}=0,342 X_{1}+0,377 X_{2} \\
Y_{2}=0,314 X_{1}+0,283 X_{2}+0,287 Y_{1}
\end{gathered}
$$

Based on the equation above, the total effect can be obtained, namely:

$$
\begin{gathered}
Y_{\text {total }}=0,342 X_{1}+0,377 X_{2}+0,287 Y_{1}\left(0,314 X_{1}+0,283 X_{2}\right) \\
=0,342 X_{1}+0,377 X_{2}+0,090 X_{1}+0,081 X_{2} \\
Y_{\text {total }}=0,432 X_{1}+0,458 X_{2}
\end{gathered}
$$

\begin{tabular}{|c|c|c|c|c|c|c|}
\hline \multirow[t]{2}{*}{ Variable } & \multicolumn{2}{|c|}{ Direct Effect } & \multicolumn{2}{|r|}{ Indirect Effect } & \multicolumn{2}{|c|}{ Total Influence Variable } \\
\hline & $Y_{1}$ & $Y_{2}$ & $Y_{1}-Y_{2}$ & $\Sigma$ & $\mathrm{Y}_{2}$ & $\Sigma$ \\
\hline $\mathrm{X}_{1}$ & 0,342 & 0,314 & 0,287 & $0,342 \times 0,287=0,098$ & 0,314 & $0,314+0,098=0,412$ \\
\hline $\mathrm{X}_{2}$ & 0,377 & 0,283 & & $0,377 \times 0,287=0,108$ & 0,283 & $0,283+0,108=0,391$ \\
\hline$Y_{1}$ & 0,000 & 0,287 & & 0,000 & 0,287 & $0,287+0,000=0,287$ \\
\hline
\end{tabular}

With the result of the equation, the total influence of all research variables can be explained in the table below:

TABLE 5: Total Influence of Research Variables.

Based on Table 5, then each path can be described as follows (complete model) namely:

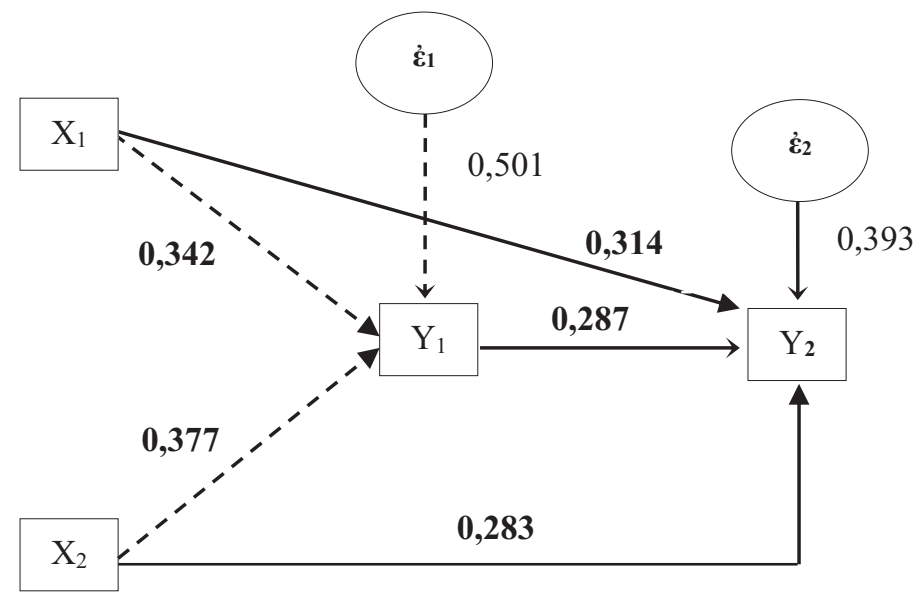

Figure 6: Complete Relationship of Structures $X_{1}, X_{2}$ and $Y_{1}$ to $Y_{2}$.

It can be concluded that the direct effect of corporate image on customer satisfaction has the most dominant coefficient $(0,377)$, when compared with the coefficient of direct 
line of perceptions of service quality to customer satisfaction $(0,342)$, and the coefficient of perceptions of service quality $(0,314)$ and corporate image $(0,283)$, and customer satisfaction $(0,287)$ to customer loyalty.

\section{Discussion}

\subsection{Effect of Perceptions of Service Quality and Corporate Image Directly on Customer Satisfaction}

Statistical analysis shows that perceptionss of service quality and corporate image have a significant effect on the customer satisfaction of Tavel Prima (Samarinda City) in a positive direction. The results of the study accept the first hypothesis, which states that perceptionss of service quality and corporate image have a significant effect on customer satisfaction.

This shows that customers feel the ability of Travel Prima (Samarinda City) to carry out the promised services (timeliness, responsiveness and empathy). So, customer feel that travel employees have a concern, individual attention to users. Perceptions of service quality that is manifested in real terms, has played an important role for customer satisfaction.

Meanwhile, the services provided to customer are indicators of the lowest corporate image in their eyes. Can be seen from complete facilities, clean rooms, and neat appearance, as well as an explanation of Travel Prima employees who are right in dealing with customer problems. The corporate image provides added value in this study. Along with previous studies, it is still rare to examine the relationship of this variable, so that the corporate image is a predictor that influences service user satisfaction, a consistent corporate image has been built by Travel Prima through good services, such as: security always opens doors to customer, customers service always serves consumers patiently, and respects guests by naming customer, teller rooms that are neatly displayed with friendly service, and fast transaction processing.

Empirical findings are relevant to previous research confirm the positive and significant relationship between the service quality, corporate image, and customer satisfaction in Pakistani service sector context [16]. 


\subsection{Effect of Perceptions of Service Quality, Corporate Image, and Satisfaction Directly on Customer Loyalty}

Statistical analysis shows that perceptions of service quality, corporate image, and satisfaction have a significant effect on the customer loyalty of Tavel Prima (Samarinda City) in a positive direction. The results of the study accept the second hypothesis, which states that perceptions of service quality, corporate image, and satisfaction have a significant effect on the customer loyalty.

Service quality is the expected level of excellence and control of the level of excellence to meet customer expectations. So, the assessment of Travel Prima customer on service quality is a reflection of evaluative perceptionss of the service received at a certain time. To be able to increase passenger loyalty, Travel Prima has improved service quality. To improve service quality, this company has revitalized physical facilities, such as: the addition of TV entertainment facilities, live music every weekend in the office area, smooking area, mosque, and clean toilets provided to support very adequate services. Other factors that can affect passenger loyalty, can also be seen from the service provided by Travel employees to passengers in accordance with the procedure.

If the peripheral quality (image) of Travel Prima is getting better, which is indicated by complete facilities and strategic locations, the loyalty of customer is increasing. This condition occurs because the company's image is a user assessment of a quality that causes travel services to be the choice and supporting quality, such as facilities and location. Facilities are all things that are physical equipment provided by the seller of services to support the convenience of customer. The facility can distinguish between service providers with one another and is an advantage for Travel Prima (Samarinda City), in order to provide satisfaction to customer. Location factor is also a place where the company does all activities to fulfill that goal with a strategic location, so the user will easily come to the service provider, so that ordinary loyalty is fulfilled.

Customer who tend to be satisfied with a product or service company will foster good loyalty. This means that high or good service user satisfaction will make consumers increasingly motivated to use the same product or service without being affected by products or services available by other companies, so that it is expected to increase the likelihood of creating high service loyalty.

Empirical findings are relevant to previous research by $[1,4,8,12]$. Consumer perceived and corporate image is observed to have a positive direct effect on the customer loyalty. Besides, proposed that high quality service is required for customer satisfaction and satisfied customers tend to be loyal customers [6]. 


\subsection{Effect of Customer Satisfaction Perceptions Service Quality and Corporate Image Indirectly on Loyalty through Customer Satisfaction}

Statistical analysis shows that perceptions of service quality and corporate image have a significant effect on loyalty through the customer satisfaction of Tavel Prima (Samarinda City) in a positive direction. The results of the study accept the third hypothesis, which states that perceptions of service quality and corporate image have a significant effect on loyalty through service customer satisfaction.

Service quality starts from customer needs and ends with the perception of customer. The good and bad quality of service is the responsibility of all parts of the Travel Prima organization. When the services provided are able to meet or exceed user expectations, they will feel satisfied. By providing good service quality to customer, it will affect satisfaction. So, service quality and satisfaction of travel service customer, is the cause of loyalty. Service quality and satisfaction greatly affect the customer loyalty.

Travel Prima image is good, has an important meaning for the survival of the company because it can create service user satisfaction. Satisfaction in the service, is the happy feeling of someone who appears after comparing the perceptions or impressions of the performance or results of travel services and expectations. The success of the company, if employees are able to provide good service, so that customer feel satisfied and in their eyes and the image becomes positive.

Empirical findings are relevant to previous research found that trust partially mediates the relationship between perceived service quality and service loyalty of Malaysian mobile phone service market [9].

\section{Conclusion}

Based on the results of the analysis and discussion in the previous section, the conclusions can be drawn from this research include:

- Perceptions of service quality and corporate image directly have a positive and significant impact on customer satisfaction.

- Perceptions of service quality, corporate image and satisfaction directly have a positive and significant effect on customer loyalty.

- Perceptions of service quality and corporate image indirectly have a positive and significant effect on loyalty through customer satisfaction Travel Prima (Samarinda City). 
The weaknesses in this study are the variables used (perceptionss of service quality, corporate image, satisfaction and customer loyalty) where the coefficient of determination $\left(R^{2}\right)$ both from sub-structure/model 1 and 2 under the number of 70,0\% (very strong category). For researchers, who in the future want to use independent variables more than this research, example: price factor, discipline of corporate employees and and others to be more interesting.

Perceptions of service quality is good, but need more enhanced facilities and supporting infrastructure, such as: website, call center or sms gateway so as can continue to provide services and information to costumers at any time without limited operating hours working hours. Continue to increase customer satisfaction by giving event or agenda promo to discount in travel packages, so hopefully can continue to win the competition and increase the satisfaction that will impact on customer loyality better. Maintaining credibility and trust by synergizing with other business partners and continue to provide excellent service, especially the accuracy of departure so it is expected to increase capasilitas corporate image in the present and future.

\section{Acknowledgement}

The researcher expressed his gratitude for the attention given by Dean of Faculty of Economics and Business, Mulawarman University (Prof. Dr. Hj. Syarifah Hudayah, M.Si); Chair of Samarinda High College of Economics Science (Ir. H. Syahril, ASK, M.Si); and Dear Commite of the 6th International Conference on Entrepreneurship (ICOEN)-2019.

\section{References}

[1] Andreassen, T. W., \& Lindestad, B. (1998). Customer loyalty and complex services, The impact of corporate image on quality, customer satisfaction and loyalty for customers with varying degrees of service expertise. International Journal of Service Industry Management, vol. 9(1), pp. 7-23.

[2] Central Statistics Agency of East Kalimantan Province (2017). Distribution and Population Density by Regency/City in East Kalimantan Province in 2016. ISSN: 0215-2266. Samarinda: CV. Sekar Mulya.

[3] Chris, D., \& Power, IV. (2000). Satisfaction: How a Great Company Hears the Voice of the Consumer. $1^{\text {st }}$ Ed (Ponziani Riga translation). Jakarta: PT. Elex Media Komputindo.

[4] Cöner, A., \& Güngör, M. O. (2002). Factors affecting customer loyalty in the competitive Turkish metropolitan retail markets. Journal of American Academy of 
Business, vol. 2(1), pp. 189-195.

[5] Hermawan, B., Basalamah, S., Djamereng, A., \& Plyriadi, A. (2017). Effect of Service Quality and Price Perception on Corporate Image, Customer Satisfaction and Customer Loyalty among Mobile Telecommunication Services Provider. IRAInternational Journal of Management \& Social Sciences, vol. 08(01), pp. 62-73.

[6] Heskett, J. L., Jones, T. O., Loveman, G. W., Sasser, W. E., \& Schlesinger, L. L. (1994). Putting the service profit chain to work. Harvard Business Review, vol. 72(2), pp. 164-174.

[7] Marzuki, S. (2000). Metodologi Riset. Muslim University of Indonesia. Yogyakarta: BPFE.

[8] Nguyen, N., \& LeBlanc, G. (1998). The mediating role of corporate image on customers' retention decisions: an investigation in financial services. Internatinal Journal of Bank Marketing, vol. 16(2), pp. 52-65.

[9] Quoquab, F., Basiruddin, R., \& Rasid, S. Z. (2013). A Structural Look at Service Loyalty: Role of Service Quality, Corporate Image, and Trus. American Journal of Economics, vol. 3(5C), pp. 177-183.

[10] Retherford, R. (1993). Statistical Models For Causal Analysis, Hawai: Program on Population East-West Center. USA: Honolulu.

[11] Sambas, A., \& Maman, A. (2009). Analisis Korelasi, Regresi dan Jalur Dalam Penelitian (Dilengkapi Aplikasi Program SPSS). Bandung: Pustaka Setia.

[12] Selnes, F. (1993). A Examination of The Effect of Product Performance on Brand Reputation, Satisfaction and Loyalty. Europeanf Journal of Marketing, vol. 27(9), pp. 19-35.

[13] Sugiyono. (2009). Metode Penelitian Kuantitatif, Kualitatif dan R\&D. Jakarta: Alfabeta.

[14] Tjiptono, F. (2007). Total quality management. Edisi Revisi. Yogyakarta: Andi.

[15] Umar, H. (2001). Riset Sumber Daya dalam Organisasi. Jakarta: PT. Gramedia Pustaka Utama.

[16] Zameer, H., Tara, A., Kausar, U., \& Mohsin, A. (2015). Impact of service quality, corporate image and customer satisfaction towards customers' perceived value in the banking sector in Pakistan. International Journal of Bank Marketing, vol. 33(4), pp. 442-456. 